\title{
Does Uremia Cause Vascular Dysfunction?
}

\author{
Philippe Brunet $^{\mathrm{a}, \mathrm{b}} \quad$ Bertrand Gondouin $^{\mathrm{a}, \mathrm{b}} \quad$ Ariane Duval-Sabatier $^{\mathrm{a}, \mathrm{b}}$ \\ Laetitia Dou $^{a} \quad$ Claire Cerini $^{a} \quad$ Françoise Dignat-George ${ }^{a} \quad$ Noémie Jourde-Chiche ${ }^{b}$ \\ Angel Argiles ${ }^{c}$ Stéphane Burtey ${ }^{a, b}$ \\ ${ }^{a}$ INSERM U608, Université Aix-Marseille, et ${ }^{b}$ Centre de Néphrologie et Transplantation Rénale, Hôpital de la \\ Conception, Marseille, et ${ }^{\mathrm{C}} \mathrm{RD}$ - Néphrologie and Groupe Rein et HTA, EA3127, Institut Universitaire de Recherche \\ Clinique IURC-UM1, Montpellier, France
}

\section{Key Words}

Chronic kidney disease $\cdot$ Vascular disease $\cdot$ Atherosclerosis • Arteriosclerosis $\cdot$ Uremic toxins

\begin{abstract}
Vascular dysfunction induced by uremia has 4 main aspects. (1) Atherosclerosis is increased. Intima-media thickness is increased, and animal studies have established that uremia accelerates atherosclerosis. Uremic toxins are involved in several steps of atherosclerosis. Leukocyte activation is stimulated by guanidines, advanced glycation end products (AGE), p-cresyl sulfate, platelet diadenosine polyphosphates, and indoxyl sulfate. Endothelial adhesion molecules are stimulated by indoxyl sulfate. Migration and proliferation of vascular smooth muscle cells (VSMC) are stimulated by local inflammation which could be triggered by indoxyl sulfate and AGE. Uremia is associated with an increase in von Willebrand factor, thrombomodulin, plasminogen activator inhibitor 1 , and matrix metalloproteinases. These factors contribute to thrombosis and plaque destabilization. There is also a decrease in nitric oxide (NO) availability, due to asymmetric dimethylarginine (ADMA), AGE, and oxidative stress. Moreover, circulating endothelial microparticles (EMP) are increased in uremia, and inhibit the NO pathway. EMP are
\end{abstract}

induced in vitro by indoxyl sulfate and p-cresyl sulfate. (2) Arterial stiffness occurs due to the loss of compliance of the vascular wall which induces an increase in pulse pressure leading to left ventricular hypertrophy and a decrease in coronary perfusion. Implicated uremic toxins are ADMA, AGE, and oxidative stress. (3) Vascular calcifications are increased in uremia. Their formation involves a transdifferentiation process of VSMC into osteoblast-like cells. Implicated uremic toxins are mainly inorganic phosphate, as well as reactive oxygen species, tumor necrosis factor and leptin. (4) Abnormalities of vascular repair and neointimal hyperplasia are due to VSMC proliferation and lead to severe reduction of vascular lumen. Restenosis after coronary angioplasty is higher in dialysis than in nondialysis patients. Arteriovenous fistula stenosis is the most common cause of thrombosis. Uremic toxins such as indoxyl sulfate and some guanidine compounds inhibit endothelial proliferation and wound repair. Endothelial progenitor cells which contribute to vessel repair are decreased and impaired in uremia, related to high serum levels of $\beta_{2}$-microglobulin and indole-3 acetic acid. Overall, there is a link between kidney function and cardiovascular risk, as emphasized by recent meta-analyses. Moreover, an association has been reported between cardiovascular mortality and uremic toxins such as indoxyl sulfate, $\mathrm{p}$ cresol and p-cresyl sulfate.

Copyright ๑ 2011 S. Karger AG, Basel

\section{KARGER \\ Fax +4161306 1234 \\ E-Mail karger@karger.ch}

www.karger.com
(C) 2011 S. Karger AG, Basel

$1420-4096 / 11 / 0344-0284 \$ 38.00 / 0$

Accessible online at:

www.karger.com/kbr
P. Brunet

Centre de Néphrologie et de Transplantation Rénale, Hôpital de la Conception 147, Bd Baille

FR-13005 Marseille (France)

Tel. +334913823 06, E-Mail philippe.brunet@ap-hm.fr 
Table 1. Events observed during the various aspects of uremic vascular dysfunction

\begin{tabular}{ll}
\hline Aspects & Events \\
\hline $\begin{array}{l}\text { Athero- } \\
\text { sclerosis }\end{array}$ & $\begin{array}{l}\text { Increased intima-media thickness } \\
\text { Lesions in autopsy series } \\
\text { Accelerated atherosclerosis in Apo-E-deficient } \\
\text { mice } \\
\text { Abnormal flow-mediated vasodilation } \\
\text { Circulating endothelial microparticles }\end{array}$ \\
\hline Arterial & $\begin{array}{l}\text { Stiffening and dilatation of the aorta and major } \\
\text { arteries }\end{array}$ \\
stiffness & $\begin{array}{l}\text { Increase in pulse pressure } \\
\text { Increase in aortic pulse wave velocity }\end{array}$ \\
& $\begin{array}{l}\text { Left ventricular hypertrophy } \\
\text { Decrease in coronary perfusion } \\
\text { Abnormal flow-mediated dilatation } \\
\text { Circulating endothelial microparticles }\end{array}$ \\
\hline $\begin{array}{l}\text { Vascular } \\
\text { calcifications }\end{array}$ & $\begin{array}{l}\text { Intimal calcification, part of the atherosclerosis } \\
\text { process } \\
\text { Medial calcification, part of the arterial } \\
\text { stiffening }\end{array}$ \\
\hline $\begin{array}{l}\text { Impaired } \\
\text { vascular repair } \\
\text { and neointimal }\end{array}$ & $\begin{array}{l}\text { Restenosis after percutaneous coronary } \\
\text { angioplasty } \\
\text { Stenosis of the venous part of the fistula, } \\
\text { main cause of fistula thrombosis }\end{array}$ \\
\hline
\end{tabular}

Vascular dysfunction that occurs in patients with chronic kidney disease (CKD) has various aspects including atherosclerosis, arterial stiffness, vascular calcifications, and intimal hyperplasia. The enumeration of the manifestations of these aspects is presented in table 1 . One common mechanism for these vascular abnormalities is endothelial dysfunction, which is more or less associated with each of them. The aim of this article is to show the impact of specific uremic factors on vascular dysfunction in uremia. The list of the uremic toxins involved in vascular dysfunction is shown in table 2 . The relationships between vascular abnormalities and endothelial dysfunction will be particularly underlined.

\section{Atherosclerosis}

In 1974, the report of Lindner et al. [1] was the first to show that a high proportion of chronic hemodialysis (HD) patients die from cardiovascular complications. This observation was attributed to accelerated atherosclerosis, and was subsequently confirmed by several
Table 2. Enumeration of the uremic toxins involved in vascular dysfunction

\begin{tabular}{|c|c|}
\hline Uremic toxins & Effect \\
\hline $\begin{array}{l}\text { Guanidine } \\
\text { compounds }\end{array}$ & $\begin{array}{l}\text { Leukocyte activation } \\
\text { Decrease in endothelial proliferation }\end{array}$ \\
\hline AGE & $\begin{array}{l}\text { Leukocyte activation } \\
\text { Stimulation of ROS } \\
\text { Stimulation of peroxynitrite generation } \\
\text { Inhibition of NO synthase activity } \\
\text { Reduction of the digestibility of collagen and } \\
\text { matrix proteins }\end{array}$ \\
\hline $\begin{array}{l}\text { p-cresyl } \\
\text { sulfate }\end{array}$ & $\begin{array}{l}\text { Leukocyte activation } \\
\text { Stimulation of circulating endothelial } \\
\text { microparticles } \\
\text { Association with mortality }\end{array}$ \\
\hline $\begin{array}{l}\text { Indoxyl } \\
\text { sulfate }\end{array}$ & $\begin{array}{l}\text { Reduction of endothelial proliferation } \\
\text { Stimulation of monocyte chemoattracant } \\
\text { protein 1, intercellular adhesion molecule } 1 \\
\text { and E-selectin expression on endothelial cells } \\
\text { Stimulation of the production of ROS by } \\
\text { endothelial cells } \\
\text { Stimulation of circulating endothelial } \\
\text { microparticles } \\
\text { Association with mortality }\end{array}$ \\
\hline ADMA & Inhibition of NO synthase \\
\hline Phosphate & $\begin{array}{l}\text { Stimulation of the transdifferentiation of } \\
\text { VSMC into osteoblast-like cells }\end{array}$ \\
\hline $\begin{array}{l}\text { Tumor necrosis } \\
\text { factor }\end{array}$ & $\begin{array}{l}\text { Stimulation of the transdifferentiation of } \\
\text { VSMC into osteoblast-like cells }\end{array}$ \\
\hline Leptin & $\begin{array}{l}\text { Stimulation of the transdifferentiation of } \\
\text { VSMC into osteoblast-like cells }\end{array}$ \\
\hline$\beta_{2}$-microglobulin & $\begin{array}{l}\text { Associated with low levels of endothelial } \\
\text { progenitor cells }\end{array}$ \\
\hline $\begin{array}{l}\text { Indole-3 } \\
\text { acetic acid }\end{array}$ & $\begin{array}{l}\text { Associated with low levels of endothelial } \\
\text { progenitor cells }\end{array}$ \\
\hline
\end{tabular}

studies (table 1). Schwartz et al. [2] showed in autopsy samples that media thickness of coronary arteries was significantly higher in uremic patients compared to controls. Nakano et al. [3] observed that frequencies of advanced atherosclerotic lesions increased gradually as the glomerular filtration rate decreased. Oh et al. [4] also demonstrated that carotid intima-media thickness, an early marker of atherosclerosis, was increased in young adult uremic patients compared with matched control subjects. Animal studies in apolipoprotein-E-deficient 
mice have established that uremia accelerates atherosclerosis [5-7]. More and more studies show the involvement of uremic toxins and endothelial dysfunction in several aspects of uremic atherosclerosis. The first step is the adhesion of activated leukocytes to endothelium [8]. Leukocyte activation could be stimulated by several guanidine compounds $[9,10]$, advanced glycation end products (AGE) [11], and p-cresyl sulfate [12]. The expression of endothelial adhesion molecules is increased in uremia. It was recently shown that indoxyl sulfate enhanced the expression of monocyte chemoattractant protein 1, intercellular adhesion molecule 1, and E-selectin in cultured endothelial cells [13-15].

The second step is the local inflammatory reaction that stimulates migration and proliferation of vascular smooth muscle cells (VSMC). The production of reactive oxygen species (ROS) in endothelial cells, which is stimulated by indoxyl sulfate, may contribute to this inflammatory reaction [16]. In a uremic mouse model, atherosclerotic lesions were characterized by accumulation of nitrotyrosine, which is a marker of ROS-protein interaction [5, 6], and high-level expression of receptors for AGE [6]. AGE increase inflammatory responses and the generation of oxidant species such as peroxynitrite $[17,18]$. The growth of VSMC is also stimulated by diadenosine polyphosphates, which are increased in platelets from CKD patients [19].

A later step of atherosclerosis is the occurrence of a rupture of the lesion and a thrombotic event. This is favored in uremia by the impairment of endothelial antithrombotic properties, which is revealed by an increase in plasma levels of von Willebrand factor, thrombomodulin, and plasminogen activator inhibitor 1 [20]. Matrix metalloproteinases may also be involved in the rupture of the lesion. They regulate the proteolysis of the vascular extracellular matrix and are crucial for plaque destabilization [21,22]. An increase in the levels of some matrix metalloproteinases was recently described in the serum or the vessels of uremic patients [21,22].

An important indicator of endothelial dysfunction involved in uremic atherosclerosis is abnormal flow-mediated dilatation of the brachial artery which is representative of the impairment in endothelium nitric oxide (NO) synthesis in the brachial and coronary vascular beds [23]. NO plays a crucial role in vascular protection because it inhibits proliferation and migration of VSMC, expression of adhesion molecules, and platelet aggregation [24]. Thus, the lack of availability of NO is a major factor in the occurrence of atherosclerosis. The uremic environment may reduce the availability of NO in two ways. First, NO synthase activity is reduced by ROS, AGE, and asymmetric dimethylarginine (ADMA). AGE are able to quench $\mathrm{NO}$ and increase the generation of oxidant species such as peroxynitrite $[17,18,25]$. ADMA is a natural inhibitor of NO synthase, and serum ADMA levels are strongly correlated with impaired flow-mediated vasodilation [26] and with carotid intima-media thickness [27]. Second, uremia is associated with an increase in circulating endothelial microparticles (EMP), whose role in endothelial dysfunction has recently been described [28]. EMP are small vesicular fragments of the endothelial cell membrane released during activation or apoptosis, and they are increased in relation to loss of flow-mediated dilatation in uremic patients [28]. In vitro studies suggest that EMP represent specific inhibitors of the endothelial NO pathway [28]. Uremic toxins could be directly involved in the increase in circulating EMP levels since in vitro experiments showed that indoxyl sulfate and p-cresyl sulfate stimulated the release of EMP by cultured endothelial cells $[29,30]$.

\section{Arterial Stiffness}

Arterial stiffening occurs due to the loss of compliance of the vascular wall. This is linked to a disequilibrium of its two prominent scaffolding proteins, collagen and elastin, with the overproduction of abnormal collagen and diminished quantities of elastin. This leads to arterial remodeling characterized by stiffening and dilatation of the aorta and major arteries [25]. The principal pathophysiological consequence of arterial stiffness is decreased arterial distensibility. Aortic stiffness induces an increase in systolic blood pressure and a decrease in diastolic blood pressure, leading to an increase in pulse pressure, and is also associated with an increase in aortic pulse wave velocity with early wave reflections. These hemodynamic alterations induce left ventricular hypertrophy associated with a decrease in coronary perfusion [31].

Blacher et al. [32] demonstrated in a cohort of $241 \mathrm{HD}$ patients that aortic pulse wave velocity, the classical marker of arterial stiffness, was an independent predictor of cardiovascular and all-cause mortality. Moreover, an association between left ventricular hypertrophy and death has been reported in CKD patients [33] as well as a relation between low diastolic pressure and mortality [34]. Compromised coronary perfusion is a classical feature of uremia. Cardiac ischemia and alterations in subendocardial perfusion are frequently observed in uremic patients despite patent coronary arteries [35]. 
Endothelial function affects arterial stiffness through influencing VSMC tone. The dilator effects of endothelium are under the control of the activity of the endothelial NO synthase. It has been shown that flow-mediated dilatation is inversely associated with aortic stiffening [36]. As mentioned above, the NO pathway may be inhibited directly by ROS, AGE and ADMA, and indirectly by EMP possibly induced in uremia by the uremic toxins indoxyl sulfate and p-cresyl sulfate [29, 30]. Circulating EMP were correlated with elevated pulse wave velocity in patients with CKD $[28,37]$.

Other aspects contribute to arterial stiffness during uremia. Arterial stiffening could occur in response to increased wall stress from hypertension. The renin-angiotensin-aldosterone system is activated and could increase the extracellular matrix collagen content and VSMC proliferation. AGE could reduce digestibility of collagen and other extracellular matrix proteins by forming irreversible cross-links [38]. AGE-linked collagen is stiffer and less susceptible to hydrolytic turnover. This results in an accumulation of structurally inadequate collagen molecules [39]. Similarly, elastin molecules are susceptible to AGE cross-linking reducing the elastic matrix of the wall [40].

\section{Vascular Calcifications}

Vascular calcifications classically occur in two locations, the intima and the media. Intimal calcifications are part of the atherosclerosis process. They are limited to large and medium-sized conduit arteries. Although they are not specific to $\mathrm{CKD}$, calcifications of coronary arteries are 2- to 5-fold more frequent in CKD patients than in age-matched individuals with angiographically proven coronary artery disease [41].

Medial calcifications occur in elastin fibers around VSMC in the absence of atherosclerosis and are seen primarily in CKD or diabetes. They occur in arteries of any size [42]. The histological prevalence of medial calcifications in radial arteries was 45 -fold greater in CKD patients compared with those without CKD [42]. What are the consequences of vascular calcifications? It is unclear whether intimal calcifications are deleterious because calcifications are not associated with unstable atherosclerosis plaques [43]. On the other hand, calcifications of the media are certainly deleterious because they are associated with arterial stiffening [44]. London et al. [45] performed a study in $202 \mathrm{HD}$ subjects with CKD, demonstrating a relationship between calcification score and mortality.

Uremia Causes Vascular Dysfunction
What is the mechanism of these vascular calcifications? Recent data support a role of osteoblast-like cells that secrete bone matrix proteins [46]. Matrix deposits in the vessel walls may result from an active cellular process with transdifferentiation of VSMC into osteoblast-like cells leading to deposition of an osteogenic type of extracellular matrix. The most important inducer of transdifferentiation of the VSMC into osteoblast-like cells is inorganic phosphate. Other uremic toxins are probably also involved. It was shown that uremic serum induced calcification of VSMC independently of phosphate concentrations [47]. Inducers present in uremic serum appear to act via a common mechanism that involves regulation of a specific transcriptional factor of the osteoblast-like phenotype: core-binding factor $\alpha_{1}$ [48]. Some of these inducers could be ROS, tumor necrosis factor, and leptin [49]. Another hypothesis proposed by Massy and colleagues [50] suggests that an imbalance between osteoblast-like and osteoclast-like cell activities would favor the calcification process in the vascular wall. They could demonstrate that inorganic phosphate inhibits the differentiation of osteoclasts. The relationship between vascular calcification and endothelial dysfunction has not been fully elucidated. However, in 124 patients with suspected coronary artery disease, Huang et al. [51] demonstrated that enhanced coronary artery calcification was independently associated with endothelial dysfunction assessed by a decrease in flow-mediated vasodilation. The endothelial activation has also been associated with calcifications in aortic valves [52]. One could imagine that a similar mechanism occurs in other vascular tissues.

\section{Impaired Vascular Repair and Neointimal Hyperplasia}

Neointimal hyperplasia is a frequent event occurring in response to vascular injury. This is a complex process, classically believed to be the consequence of VSMC proliferation and migration, and the synthesis of extracellular matrix. It is also characterized by an increased expression of mediators and cytokines and by neovascularization within the media, neointima and adventitia [53]. Recently, it has been proposed that progenitor cells attracted to the site of vascular injury could be involved in the neointimal lesion [54]. Neointimal hyperplasia is a poorly explained phenomenon. For example, the exact origin of VSMC observed in neointimal hyperplasia is not known with certainty. They could be transformed fibroblasts migrating from the adventitia or VSMC migrat-

Kidney Blood Press Res 2011;34:284-290 
ing from the media [53]. There is a close link between neointimal hyperplasia and endothelium function since endothelial cells are supposed to control intimal hyperplasia. After a vascular lesion, it is assumed that the earlier the reendothelialization is achieved, the less neointima extends [55].

The clinical consequences of neointimal hyperplasia are severe. They complicate the management of coronary artery disease and they decrease the survival of HD arteriovenous fistula. Concerning coronary artery disease in patients with CKD, restenosis is the major clinical limitation of percutaneous coronary angioplasty. The restenosis rate is higher in dialysis than in nondialysis patients [56]. Regarding arteriovenous fistula, stenosis due to intimal hyperplasia is the most common cause of long-term thrombosis [53].

Although mechanisms of neointimal hyperplasia in CKD patients are poorly understood, recent data could give new insights into vascular repair in uremic patients. It has been demonstrated in vitro that some uremic toxins such as indoxyl sulfate and guanidine compounds inhibit endothelial proliferation and wound repair $[10,57]$. Moreover, endothelial progenitor cells, which contribute to vessel repair and neovascularization, undergo a decrease in their ability to migrate in the presence of uremic serum [58]. CKD patients also generally have a decreased number of circulating endothelial progenitor cells [59]. The influence of the uremic milieu was confirmed by the observation that high serum levels of $\beta_{2}$-microglobulin and indole- 3 acetic acid are associated with low numbers of circulating CD34+CD133+ progenitor cells [60]. A spectacular indirect argument that supports the negative effect of uremic toxicity on vascular repair is given by the results of Chan et al. [61] showing that very long and frequent HD is associated with restoration of impaired endothelial progenitor cells, and improvement in peripheral arterial disease [62]. Moreover, recent experiments in rats with or without $\mathrm{CKD}$, and equipped with an arteriovenous fistula, showed that shrinking and calcification of the fistula vein media occurred only in rats with CKD [63]. These data support that uremia has a negative influence on neointimal hyperplasia and vascular repair.

\section{Cardiovascular Mortality}

Overall, the different aspects of vascular dysfunction described in this article contribute to the huge cardiovascular mortality observed in patients with CKD. In 1998, a classic publication from Foley et al. [64] reported that the cardiovascular mortality rate in dialysis patients was 10-30 times higher than that in the general population despite stratification for sex, race and presence of diabetes. In 2005, the European Uremic Toxin Work Group performed an evidence-based evaluation including 85 publications and covering more than 500,000 subjects, which clearly suggested a link between kidney dysfunction and cardiovascular risk [65]. This link between CKD and cardiovascular and all-cause mortality in the general population has recently been confirmed by a collaborative meta-analysis including 21 publications [66]. The impact of uremia on cardiovascular disease is also supported by the recently demonstrated association between cardiovascular mortality and uremic toxins such as indoxyl sulfate [67], p-cresol [68], and free p-cresyl sulfate [69]. All these new data begin to unravel the complex picture of cardiovascular risk factors in uremia and strongly suggest new targets for prevention in CKD patients.

\section{Disclosure Statement}

The authors report no potential conflict of interest relevant to this article.

\section{References}

1 Lindner A, Charra B, Sherrard DJ, Scribner $\mathrm{BH}$ : Accelerated atherosclerosis in prolonged maintenance hemodialysis. N Engl J Med 1974;290:697-701.

-2 Schwarz U, Buzello M, Ritz E, Stein G, Raabe G, Wiest G, Mall G, Amann K: Morphology of coronary atherosclerotic lesions in patients with end-stage renal failure. Nephrol Dial Transplant 2000;15:218-223.
-3 Nakano T, Ninomiya T, Sumiyoshi S, Fujii H, Doi Y, Hirakata H, Tsuruya K, Iida M, Kiyohara Y, Sueishi K: Association of kidney function with coronary atherosclerosis and calcification in autopsy samples from Japanese elders: the Hisayama study. Am J Kidney Dis 2010;55:21-30.

4 Oh J, Wunsch R, Turzer M, Bahner M, Raggi P, Querfeld U, Mehls O, Schaefer F: Advanced coronary and carotid arteriopathy in young adults with childhood-onset chronic renal failure. Circulation 2002;106:100-105.
5 Bro S, Bentzon JF, Falk E, Andersen CB, Olgaard K, Nielsen LB: Chronic renal failure accelerates atherogenesis in apolipoprotein E-deficient mice. J Am Soc Nephrol 2003;14: 2466-2474.

6 Buzello M, Törnig J, Faulhaber J, Ehmke H, Ritz E, Amann K: The apolipoprotein e knockout mouse: a model documenting accelerated atherogenesis in uremia. J Am Soc Nephrol 2003;14:311-316. 
7 Massy ZA, Ivanovski O, Nguyen-Khoa T, Angulo J, Szumilak D, Mothu N, Phan O, Daudon M, Lacour B, Drüeke TB, Muntzel MS: Uremia accelerates both atherosclerosis and arterial calcification in apolipoprotein $\mathrm{E}$ knockout mice. J Am Soc Nephrol 2005; 16: 109-116.

8 Ross R: Atherosclerosis-an inflammatory disease. N Engl J Med 1999;340:115-126.

$\checkmark$ Glorieux GL, Dhondt AW, Jacobs P, Van Langeraert J, Lameire NH, De Deyn PP, Vanholder RC: In vitro study of the potential role of guanidines in leukocyte functions related to atherogenesis and infection. Kidney Int 2004;65:2184-2192.

-10 Schepers E, Glorieux G, Dou L, Cerini C, Gayrard N, Louvet L, Maugard C, Preus P, Rodriguez-Ortiz M, Argiles A, Brunet P, Cohen G, Jankowski J, Jankowski V, Massy Z, Rodriguez M, Vanholder R, European Uremic Toxin Work Group (EUTox): Guanidino compounds as cause of cardiovascular damage in chronic kidney disease: an in vitro evaluation. Blood Purif 2010;30:277-287.

-11 Hou FF, Ren H, Owen WF Jr, Guo ZJ, Chen PY, Schmidt AM, Miyata T, Zhang X: Enhanced expression of receptor for advanced glycation end products in chronic kidney disease. J Am Soc Nephrol 2004; 15:18891896.

-12 Schepers E, Meert N, Glorieux G, Goeman J, Van der Eycken J, Vanholder R: P-cresylsulphate, the main in vivo metabolite of $\mathrm{p}$-cresol, activates leucocyte free radical production. Nephrol Dial Transplant 2007;22:592596.

13 Masai N, Tatebe J, Yoshino G, Morita T: Indoxyl sulfate stimulates monocyte chemoattractant protein-1 expression in human umbilical vein endothelial cells by inducing oxidative stress through activation of the NADPH oxidase-nuclear factor- $\kappa \mathrm{B}$ pathway. Circ J 2010;74:2216-2224.

-14 Ito S, Osaka M, Higuchi Y, Nishijima F, Ishii $\mathrm{H}$, Yoshida M: Indoxyl sulfate induces leukocyte-endothelial interactions through upregulation of E-selectin. J Biol Chem 2010; 285:38869-38875.

-15 Tumur Z, Shimizu H, Enomoto A, Miyazaki $\mathrm{H}$, Niwa T: Indoxyl sulfate upregulates expression of ICAM-1 and MCP-1 by oxidative stress-induced NF-kappaB activation. Am J Nephrol 2010;31:435-441.

-16 Dou L, Jourde-Chiche N, Faure V, Cerini C, Berland Y, Dignat-George F, Brunet P: The uremic solute indoxyl sulfate induces oxidative stress in endothelial cells. J Thromb Haemost 2007;5:1302-1308.

17 Rojas A, Romay S, González D, Herrera B, Delgado R, Otero K: Regulation of endothelial nitric oxide synthase expression by albumin-derived advanced glycosylation end products. Circ Res 2000;86:E50-E54.
8 Yan SD, Schmidt AM, Anderson GM, Zhang J, Brett J, Zou YS, Pinsky D, Stern D: Enhanced cellular oxidant stress by the interaction of advanced glycation end products with their receptors/binding proteins. J Biol Chem 1994;269:9889-9897.

19 Jankowski J, Hagemann J, Yoon MS, van der Giet M, Stephan N, Zidek W, Schluter H, Tepel M: Increased vascular growth in hemodialysis patients induced by platelet-derived diadenosine polyphosphates. Kidney Int 2001;59:1134-1141.

20 Stam F, van Guldener C, Schalkwijk CG, ter Wee PM, Donker AJ, Stehouwer CD: Impaired renal function is associated with markers of endothelial dysfunction and increased inflammatory activity. Nephrol Dial Transplant 2003;18:892-898.

21 Chung AW, Yang HH, Kim JM, Sigrist MK, Chum E, Gourlay WA, Levin A: Upregulation of matrix metalloproteinase-2 in the arterial vasculature contributes to stiffening and vasomotor dysfunction in patients with chronic kidney disease. Circulation 2009; 120:792-801.

22 Coll B, Rodríguez JA, Craver L, Orbe J, Martínez-Alonso M, Ortiz A, Díez J, Beloqui O, Borras M, Valdivielso JM, Fernández E, Páramo JA: Serum levels of matrix metalloproteinase-10 are associated with the severity of atherosclerosis in patients with chronic kidney disease. Kidney Int 2010;78:12751280.

23 Passauer J, Bussemaker E, Range U, Plug M, Gross P: Evidence in vivo showing increase of baseline nitric oxide generation and impairment of endothelium-dependent vasodilation in normotensive patients on chronic hemodialysis. J Am Soc Nephrol 2000;11: 1726-1734.

24 Vanhoutte PM, Feletou M, Taddei S: Endothelium-dependent contractions in hypertension. Br J Pharmacol 2005;144:449-458.

25 Zieman SJ, Melenovsky V, Kass DA: Mechanisms, pathophysiology, and therapy of arterial stiffness. Arterioscler Thromb Vasc Biol 2005;25:932-943.

-26 Fliser D, Kielstein JT, Haller H, Bode-Böger SM: Asymmetric dimethylarginine: a cardiovascular risk factor in renal disease? Kidney Int Suppl 2003;84:S37-S40.

27 Nanayakkara PW, Teerlink T, Stehouwer CD, Allajar D, Spijkerman A, Schalkwijk C, Ter Wee PM, van Guldener C: Plasma asymmetric dimethylarginine (ADMA) concentration is independently associated with carotid intima-media thickness and plasma soluble vascular cell adhesion molecule-1 (sVCAM-1) concentration in patients with mild-to-moderate renal failure. Kidney Int 2005;68:2230-2236.

-28 Amabile N, Guerin AP, Leroyer A, Mallat Z, Nguyen C, Boddaert J, London GM, Tedgui A, Boulanger CM: Circulating endothelial microparticles are associated with vascular dysfunction in patients with end-stage renal failure. J Am Soc Nephrol 2005; 16:3381-3388.
29 Faure V, Dou L, Sabatier F, Cerini C, Sampol J, Berland Y, Brunet P, Dignat-George F: Elevation of circulating endothelial microparticles in patients with chronic renal failure. J Thromb Haemost 2006;4:566-573.

30 Meijers BK, Van Kerckhoven S, Verbeke K, Dehaen W, Vanrenterghem Y, Hoylaerts MF, Evenepoel P: The uremic retention solute $\mathrm{p}$ cresyl sulfate and markers of endothelial damage. Am J Kidney Dis 2009;54:891-901.

-31 London GM, Guerin AP: Influence of arterial pulse and reflected waves on blood pressure and cardiac function. Am Heart J 1999; 138:220-224.

32 Blacher J, Guerin AP, Pannier B, Marchais SJ, Safar ME, London GM: Impact of aortic stiffness on survival in end-stage renal disease. Circulation 1999;99:2434-2439.

33 Silberberg JS, Barre PE, Prichard SS, Sniderman AD: Impact of left ventricular hypertrophy on survival in end-stage renal disease. Kidney Int 1989;36:286-290.

34 Iseki K, Miyasato F, Tokuyama K, Nishime $\mathrm{K}$, Uehara H, Shiohira Y, Sunagawa H, Yoshihara K, Yoshi S, Toma S, Kowatari T, Wake T, Oura T, Fukiyama K: Low diastolic blood pressure, hypoalbuminemia, and risk of death in a cohort of chronic hemodialysis patients. Kidney Int 1997;51:1212-1217.

35 Rostand SG, Kirk KA, Rutsky EA: Dialysisassociated ischemic heart disease: insights from coronary angiography. Kidney Int 1984;25:653-659.

36 Kopeć G, Podolec P, Podolec J, Rubiś P, Zmudka K, Tracz W: Atherosclerosis progression affects the relationship between endothelial function and aortic stiffness. Atherosclerosis 2009;204:250-254.

- 37 Dursun I, Poyrazoglu HM, Gunduz Z, Ulger H, Yykylmaz A, Dusunsel R, Patyroglu T, Gurgoze M: The relationship between circulating endothelial microparticles and arterial stiffness and atherosclerosis in children with chronic kidney disease. Nephrol Dial Transplant 2009;24:2511-2518.

- 38 Miyata T, van Ypersele de Strihou C, Kurokawa K, Baynes JW: Alterations in nonenzymatic biochemistry in uremia: origin and significance of 'carbonyl stress' in long-term uremic complications. Kidney Int 1999;55: 389-399.

-39 Verzijl N, DeGroot J, Thorpe SR, Bank RA, Shaw JN, Lyons TJ, Bijlsma JW, Lafeber FP, Baynes JW, TeKoppele JM: Effect of collagen turnover on the accumulation of advanced glycation end products. J Biol Chem 2000; 275:39027-39031.

40 Konova E, Baydanoff S, Atanasova M, Velkova A: Age-related changes in the glycation of human aortic elastin. Exp Gerontol 2004; 39:249-254.

41 Braun J, Oldendorf M, Moshage W, Heidler R, Zeitler E, Luft FC: Electron beam computed tomography in the evaluation of cardiac calcification in chronic dialysis patients. Am J Kidney Dis 1996;27:394-401. 
-42 O’Neill WC, Lomashvili KA: Recent progress in the treatment of vascular calcification. Kidney Int 2010;78:1232-1239.

-43 Huang PH, Chen LC, Leu HB, Ding PY, Chen JW, Wu TC, Lin SJ: Enhanced coronary calcification determined by electron beam CT is strongly related to endothelial dysfunction in patients with suspected coronary artery disease. Chest 2005;128:810-815.

-44 Raggi P, Bellasi A, Ferramosca E, Islam T, Muntner P, Block GA: Association of pulse wave velocity with vascular and valvular calcification in hemodialysis patients. Kidney Int 2007;71:802-807.

45 London GM, Guérin AP, Marchais SJ, Métivier F, Pannier B, Adda H: Arterial media calcification in end-stage renal disease: impact on all-cause and cardiovascular mortality. Nephrol Dial Transplant. 2003;18:17311740.

46 Moe SM, Chen NX: Pathophysiology of vascular calcification in chronic kidney disease. Circ Res 2004;95:560-567.

$\checkmark 47$ Chen NX, O’Neill KD, Duan D, Moe SM: Phosphorus and uremic serum up-regulate osteopontin expression in vascular smooth muscle cells. Kidney Int 2002;62:1724-1731.

-48 Moe SM, Duan D, Doehle BP, O’Neill KD, Chen NX: Uremia induces the osteoblast differentiation factor Cbfa1 in human blood vessels. Kidney Int 2003;63:1003-1011.

49 Mizobuchi M, Towler D, Slatopolsky E: Vascular calcification: the killer of patients with chronic kidney disease. J Am Soc Nephrol 2009;20:1453-1464.

- 50 Mozar A, Haren N, Chasseraud M, Louvet L, Mazière C, Wattel A, Mentaverri R, Morlière P, Kamel S, Brazier M, Mazière JC, Massy ZA: High extracellular inorganic phosphate concentration inhibits RANK-RANKL signaling in osteoclast-like cells. J Cell Physiol 2008;215:47-54.

- 51 Huang PH, Chen LC, Leu HB, Ding PY, Chen JW, Wu TC, Lin SJ: Enhanced coronary calcification determined by electron beam CT is strongly related to endothelial dysfunction in patients with suspected coronary artery disease. Chest 2005;128:810-815.
52 Poggio P, Grau JB, Field BC, Sainger R, Seefried WF, Rizzolio F, Ferrari G: Osteopontin controls endothelial cell migration in vitro and in excised human valvular tissue from patients with calcific aortic stenosis and controls. J Cell Physiol 2010, E-pub ahead of print.

53 Lee T, Roy-Chaudhury P: Advances and new frontiers in the pathophysiology of venous neointimal hyperplasia and dialysis access stenosis. Adv Chronic Kidney Dis 2009;16: 329-338.

54 Tsai S, Butler J, Rafii S, Liu B, Kent KC: The role of progenitor cells in the development of intimal hyperplasia. J Vasc Surg 2009;49: 502-510.

55 Wang CH, Cherng WJ, Yang NI, Kuo LT, Hsu CM, Yeh HI, Lan YJ, Yeh CH, Stanford WL: Late-outgrowth endothelial cells attenuate intimal hyperplasia contributed by mesenchymal stem cells after vascular injury. Arterioscler Thromb Vasc Biol 2008;28:54-60.

56 Ota T, Umeda H, Yokota S, Miyata S, Takamura A, Sugino S, Hayashi K, Ishiki R, Takeichi Y, Iwase M, Inagaki H, Murohara T: Relationship between severity of renal impairment and 2-year outcomes after sirolimus-eluting stent implantation. Am Heart J 2009;158:92-98.

57 Dou L, Bertrand E, Cerini C, Faure V, Sampol J, Vanholder R, Berland Y, Brunet P: The uremic solutes $\mathrm{p}$-cresol and indoxyl sulfate inhibit endothelial proliferation and wound repair. Kidney Int 2004;65:442-451.

- 58 Herbrig K, Pistrosch F, Oelschlaegel U, Wichmann G, Wagner A, Foerster S, Richter $\mathrm{S}$, Gross P, Passauer J: Increased total number but impaired migratory activity and adhesion of endothelial progenitor cells in patients on long-term hemodialysis. Am J Kidney Dis 2004;44:840-849.

59 de Groot K, Bahlmann FH, Sowa J, Koenig J, Menne J, Haller H, Fliser D: Uremia causes endothelial progenitor cell deficiency. Kidney Int 2004;66:641-646.

60 Jourde-Chiche N, Dou L, Sabatier F, Calaf R, Cerini C, Robert S, Camoin-Jau L, Charpiot P, Argiles A, Dignat-George F, Brunet P: Levels of circulating endothelial progenitor cells are related to uremic toxins and vascular injury in hemodialysis patients. J Thromb Haemost 2009;7:1576-1584.

61 Chan CT, Li SH, Verma S: Nocturnal hemodialysis is associated with restoration of impaired endothelial progenitor cell biology in end-stage renal disease. Am J Physiol Renal Physiol 2005;289:F679-F684.
62 Chan CT, Mardirossian S, Faratro R, Richardson RM: Improvement in lower-extremity peripheral arterial disease by nocturnal hemodialysis. Am J Kidney Dis 2003;41:225229.

63 Langer S, Kokozidou M, Heiss C, Kranz J, Kessler T, Paulus N, Krüger T, Jacobs MJ, Lente C, Koeppel TA: Chronic kidney disease aggravates arteriovenous fistula damage in rats. Kidney Int 2010;78:1312-1321.

64 Foley RN, Parfrey PS, Sarnak MJ: Clinical epidemiology of cardiovascular disease in chronic renal disease. Am J Kidney Dis 1998; 32(suppl 3):S112-S119.

65 Vanholder R, Massy Z, Argiles A, Spasovski G, Verbeke F, Lameire N, European Uremic Toxin Work Group: Chronic kidney disease as cause of cardiovascular morbidity and mortality. Nephrol Dial Transplant 2005;20: 1048-1056.

66 Chronic Kidney Disease Prognosis Consortium, Matsushita K, van der Velde M, Astor BC, Woodward M, Levey AS, de Jong PE, Coresh J, Gansevoort RT: Association of estimated glomerular filtration rate and albuminuria with all-cause and cardiovascular mortality in general population cohorts: a collaborative meta-analysis. Lancet 2010; 375:2073-2081.

67 Barreto FC, Barreto DV, Liabeuf S, Meert N, Glorieux G, Temmar M, Choukroun G, Vanholder R, Massy ZA, European Uremic Toxin Work Group (EUTox): Serum indoxyl sulfate is associated with vascular disease and mortality in chronic kidney disease patients. Clin J Am Soc Nephrol 2009;4:1551-1558.

68 Meijers BK, Bammens B, De Moor B, Verbeke K, Vanrenterghem Y, Evenepoel P: Free p-cresol is associated with cardiovascular disease in hemodialysis patients. Kidney Int 2008;73:1174-1180.

69 Liabeuf S, Barreto DV, Barreto FC, Meert N, Glorieux G, Schepers E, Temmar M, Choukroun G, Vanholder R, Massy ZA, European Uraemic Toxin Work Group (EUTox): Free p-cresylsulphate is a predictor of mortality in patients at different stages of chronic kidney disease. Nephrol Dial Transplant 2010; 25:1183-1191. 